\title{
A NEW HECHTIA (BROMELIACEAE) FROM THE STATES OF QUERÉTARO AND HIDALGO, MEXICO
}

\author{
IVÓN M. RAMÍREZ-MORILLO \\ Centro de Investigación Científica de Yucatán, A.C. (CICY), Herbario CICY, Calle \\ 43, Num. 130, Colonia Chuburná de Hidalgo, 97200 Mérida, Yucatán, México. \\ ramirez@cicy.mx
}

\begin{abstract}
Hechtia lepidophylla is described and illustrated. A complete description including characters of staminate, pistillate, and fruiting plants is included, with details of growth pattern and ecological characteristics, as well as characters to distinguish it from species with similar vegetative and floral characters such as $H$. argentea, $H$. glomerata, and $H$. texensis.
\end{abstract}

Key words: Bromeliaceae, Hechtia, Hidalgo, Mexico, Querétaro.

\section{RESUMEN}

Se describe e ilustra Hechtia lepidophylla. Se incluye una descripción completa con características de las flores estaminadas, pistiladas y de los frutos. Asimismo, se discuten detalles de su patrón de crecimiento y características ecológicas, así como los rasgos que la distinguen de especies similares en aspectos vegetativos y florales, tales como $H$. argentea, H. glomerata y H. texensis.

Palabras clave: Bromeliaceae, Hechtia, Hidalgo, México, Querétaro.

In the Flora del Bajío y de Regiones Adyacentes area, which comprises the Mexican states of Guanajuato and Querétaro, and the northern portion of Michoacán, the family Bromeliaceae is represented by seven genera, Aechmea Ruiz \& Pav. (1 species), Bromelia L. (2 species), Catopsis Griseb. (1 species) Pitcairnia L'Hér. (4 species), and Viridantha Espejo (3 species each), Tillandsia L., the most diverse genus in the area with 31 species, and Hechtia Klotzsch with seven species, including 
the one herein reported. This results in 42 species for the area (Espejo-Serna \& López-Ferrari, pers. comm.).

Species of Hechtia are terrestrial and inhabit dry, rocky places growing as lithophytes, sometimes on vertical walls along rivers, always on well drained soils. On the basis of leaf morphology, two groups of Hechtia can be distinguished in the area of the Flora: those with minutely serrate, thinly coriaceous leaves (Hechtia lundelliorum L. B. Sm. and H. tillandsioides (André) L. B. Sm.), and those with strongly armed, spinose, thickly-fleshy leaves. In this last group, there are species with a central inflorescence such as Hechtia podantha Mez, and H. zamudioi Espejo, López-Ferrari \& I. Ramírez, and species with lateral inflorescences such as H. glomerata Zucc. and H. pretiosa Espejo \& López-Ferrari (Espejo-Serna et al. 2007, 2008).

Live plants provide many of the diagnostic characters necessary to separate Hechtia species. These include rosette shape and size, growth pattern, inflorescence origin, inflorescence characteristics for each sex, flower shape and color. As with many large, succulent, spiny plants, Hechtia species are difficult to identify with herbarium material since it is commonly fragmentary. This situation is compounded by the fact that hechtias are dioecious (one species polygamomonoecious), and the already fragmentary material also usually represents only one of the sexes. Furthermore, the sexual dimorphism of most Hechtia species on one side (differing sexes mainly on inflorescence size and flower number, fragrance presence, flower colors, and flowers texture), and the wide variation in inflorescence features (size, branch number, dimensions, etc.) on the other hand, make it difficult to circumscribe and differentiate many of the species with herbarium specimens. Field work is required to understand the limits and population variation of species in this genus. In some cases, several of the species are sympatric, making locality data itself non reliable to identify with certainty many of the taxa. To make things worse, several species only bloom rarely and blooming times are extremely brief (i.e. one week on anthesis, personal observations on cultivated plants). Furthermore, some rarely bloom irrespective of the mature age of many of the individuals (e.g. Hechtia zamudioi) making difficult to encounter fertile specimens.

Studies of herbarium material, fieldwork, and observations of several cultivated plants of a new entity, reveal vegetative and floral characters that allow distinguishing it from species with similar vegetative and floral characters. A complete description of the new entity including pistillate, staminate, and fruiting plants is herein included as well as illustrations and pictures, with useful characters to distinguish it from other species that occur in the same general area. 
Hechtia lepidophylla I. Ramírez, sp. nov. (Figures 1 A-D, 2, 3).

Similis Hechtiae glomeratae Zucc., sed diversa: habitu multirosulato (non unirosulato vel 1-2-rosulato rosulis adventitiis), laminis foliorum recurvis, utrinque lepidotis (non laminis rectis, subtus tantum dense lepidotis), spinis in medietate basali laminae crista trichomatum praeditis (non spinis glabris), ramis inflorescentiae pistillatae cylindricis, rarissime torulosis (non semper torulosis).

Terrestrial, polycarpic rosettes, growing by the formation of new rosettes in lateral or basal leaf axils of non flowering or flowering rosettes. Rhizomes very short, producing cespitose plants of several (less than ten) rosettes, growing mostly on steep rocky places. Leaves erect, rigid, succulent, forming a funnel-like rosette, curved, oriented toward one side, especially when the plant consists of a compact cluster of rosettes, leaf apices erect; foliar sheaths $4.5-5 \mathrm{~cm}$ long, 4.2-5.2 cm wide, oblong, shiny, smooth, provided with a dark brown spot in the upper middle when dry, this sometimes occupying half of the sheath, provided with a tuff of hairs on both margins on the upper region close to the blade; foliar blades triangular, acute and acuminate, $25-50 \mathrm{~cm}$ long, $2.5-3.5 \mathrm{~cm}$ wide, curved, light green, densely lepidote on both surfaces, providing the entire plant with a white hue, apex pungent, margins strongly spinose, spines 5-6 mm long, 1-2 cm apart, uncinate, light brown, mostly antrorse, those of the lower half portion of the blade with a tuff of hairs in the axils. Inflorescences lateral, erect, paniculate; scape much longer than leaves, emerging from a bundle of bracts and sheaths resembling new rosette borne in the axils of leaves, cylindrical in cross section, 4-5(-10) $\mathrm{mm}$ in diameter, light to dark brown, glabrous basally, apically slightly white-lepidote, internodes (2-)4.5-5 cm long, basal bracts of the scape polystichous, narrowly triangular, acute and acuminate, 4.5-7 cm long, 1.4-1.6 cm wide, densely imbricate, conspicuously nerved, densely lepidote abaxially, margins laxly spinose, upper scape bracts polystichous, adpressed to the peduncle, narrowly triangular, acute and acuminate, $2-3.2(-5.5) \mathrm{cm}$ long, 6-7(-9) mm wide, conspicuously lepidote abaxially, sparsely lepidote adaxially, strongly nerved, margins thin, laxly spinose. Staminate inflorescences 2-divided panicles; rachis cylindrical in cross section, $4-5 \mathrm{~mm}$ in diameter, brown, lepidote, internodes $1.5-5 \mathrm{~cm}$ long, branches polystichous, primary bracts much shorter than sterile portion of the primary branch, sometimes subtending a condensed secondary branch and then no sterile portion present, triangular, acute and acuminate, $8-12 \mathrm{~mm}$ long, 3-4 mm wide, margins spinose, lepidote abaxially, branches 15-20 per inflorescence, cylindrical in general shape, erect and forming an acute angle with the rachis, 

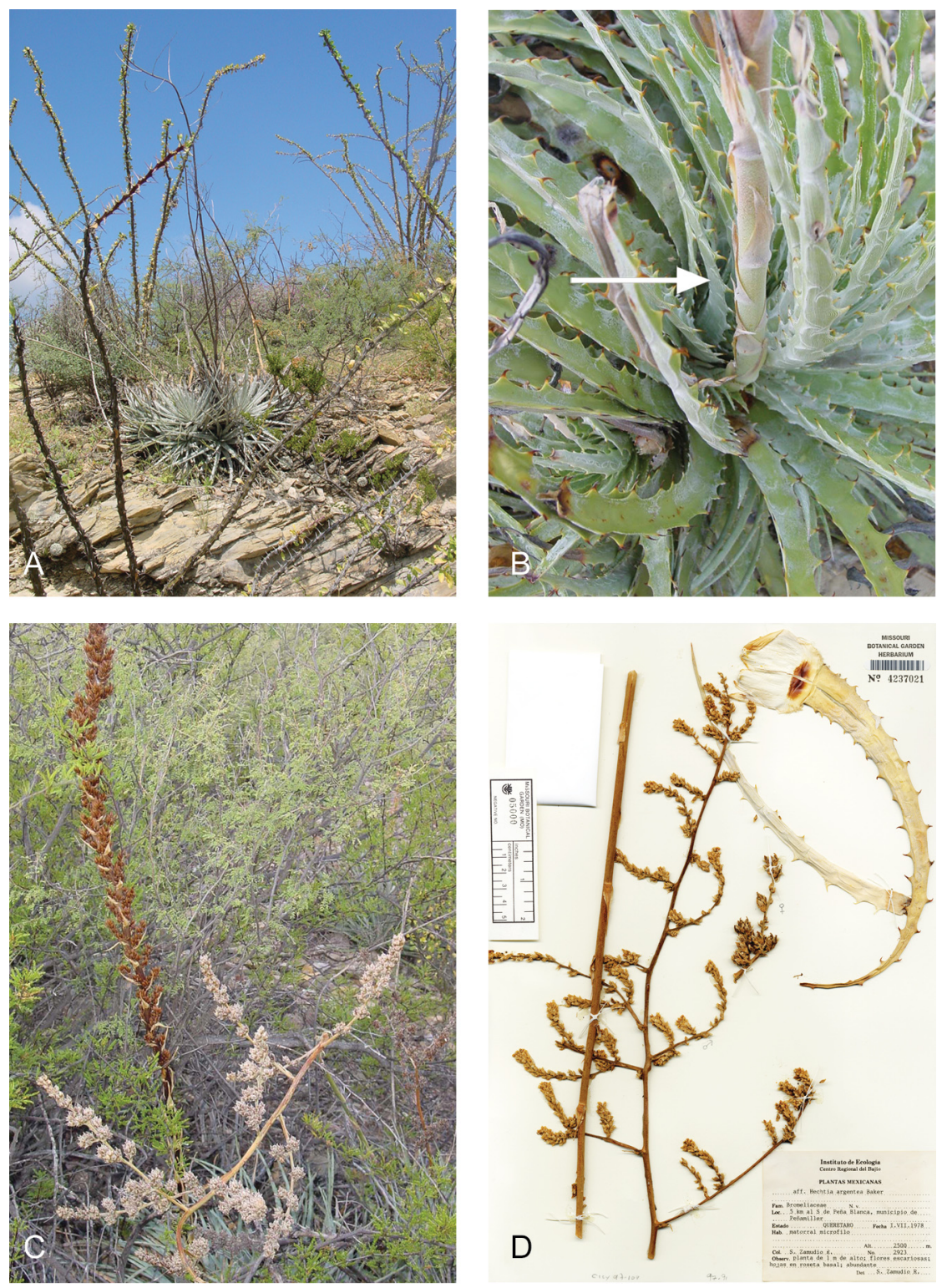

Fig. 1. A-D. Hechtia lepidophylla I. Ramírez. A. plant in habitat; B. rising of the scape, this pointed with an arrow; C. pistillate plant (at the middle), fruiting plant (far right), sympatric with a pistillate plant of Hechtia podantha (right, brown colored) in Querétaro; D. holotype (S. Zamudio 2923, MO) showing details of the curved foliar blade and staminate inflorescence structure and a fragment of a fruting branch (photographs by I. Ramírez). 
4-13(-23) cm long, rachis 1-2 mm diameter, secondary branches 1-2.5 cm long, much condensed, without sterile portion, forming an acute angle with rachis of primary branch, flowers 10-30 per branch, clustered polystichously, 4-5 mm long, some solitary along the branches, sessile; floral bract widely triangular to subquadrate, sometimes asymmetric, 7-7.1 $\mathrm{mm}$ long, 7-7.1 $\mathrm{mm}$ wide, acute and apiculate, concave, margins irregular, sinuate, 5-nervate, sometimes 1-2 of lateral nerves bifurcating, brownish in color, brown lepidote abaxially, sepals oblong, 4.2-4.5 mm long, 2.9-3 mm wide, rounded, concave, margins entire, 3-5-nervate, densely pubescent abaxia1ly, very thinly textured except at the mid nerve, petals obovate, $5.4-5.5 \mathrm{~mm}$ long, 2.9-3 mm wide, round, 5-7 nerved, sometimes 1-2 lateral nerves bifurcating, white, membranaceous, stamens erect, $4.5 \mathrm{~mm}$ long, filament broadly triangular, flattened, ca. $2.5 \mathrm{~mm}$ long, ca. $8 \mathrm{~mm}$ wide, 1-nervate, white, anther ovate, versatile, $1.3 \mathrm{~mm}$ long, $0.7 \mathrm{~mm}$ wide, pistillode obovoid, $4 \mathrm{~mm}$ long, $2 \mathrm{~mm}$ diameter, with three apical, erect lobes, $2 \mathrm{~mm}$ long. Pistillate inflorescences usually 2-divided panicles, with long primary branches and short secondary branches with clustered flowers, occasionally the inflorescences 1-divided panicles with flowers scattered along the branches, laxly arranged, scape erect, brown, smooth, cylindrical, 45-50 cm long, 6-7 $\mathrm{mm}$ in diameter, scape bracts scarious, at the base of the inflorescence longer than internodes and slightly overlapping, toward the apex much shorter than internodes, triangular, acute and long acuminate, $2-4 \mathrm{~cm}$ long, 1-1.5 cm wide, margins entire or almost entire, many-nerved, light brown, lepidote on both sides, more conspicuously so abaxially, internodes $1.5-3 \mathrm{~cm}$ long, up to $4 \mathrm{~cm}$ in the upper portion, primary bracts much shorter than the sterile portion of the branch, sterile portion of branch sometimes lacking, bracts triangular, acute and abruptly acuminate, $1-1.5 \mathrm{~cm}$ long, 5-7 mm wide, scarious, brown, margins thin, laxly serrate, lepidote, conspicuously many-nerved, branches 13-18 per inflorescence, erect, forming an acute angle with the rachis, polystichous, (2-)5-13 cm long, straight, cylindrical in cross section, 3-4 $\mathrm{mm}$ in diameter, slightly lepidote; flowers 6-12 on primary branches, pedicellate, polystichous, sometimes at the base of primary branches, a secondary branch with flowers organized in small, fasciculate clusters, with 2-8 flowers, when panicles are 1-divided, then the flowers are 10-20, laxly arranged, flowers 7-8 mm long; floral bract variable in size, $4.5-5.3 \mathrm{~mm}$ long, $4-5 \mathrm{~mm}$ wide, wide triangular, with a small apiculus, concave, densely lepidote on both surfaces, especially abaxially, central nerve thick and forming a keel on the posterior surface and forming an apiculus ca. $1 \mathrm{~mm}$ long, light brown and smooth when dry, reddish when alive, margins sinuate, 5-7 nerved, occasionally 1-2 lateral nerves bifurcated, pedicel $1 \mathrm{~mm}$ long, thick, sepals free, variable in shape and size, ovate to triangular, 4.5-4.7 $\mathrm{mm}$ long, 


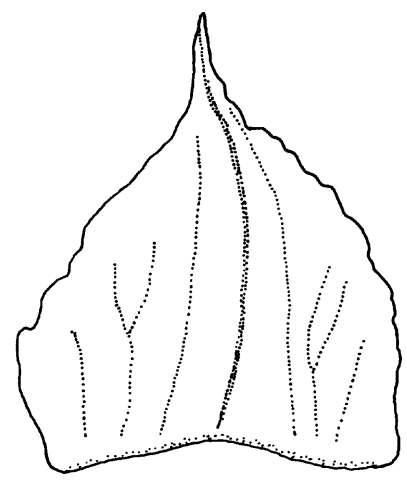

A
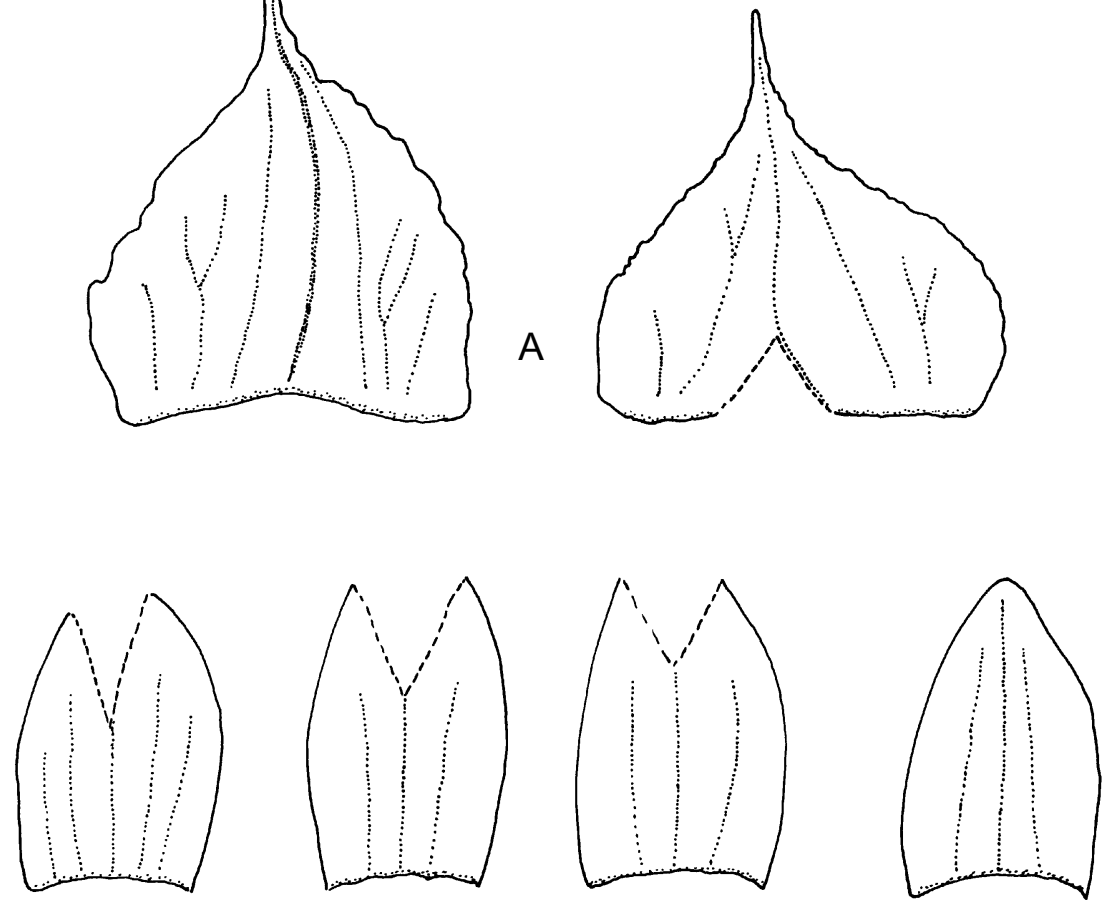

B
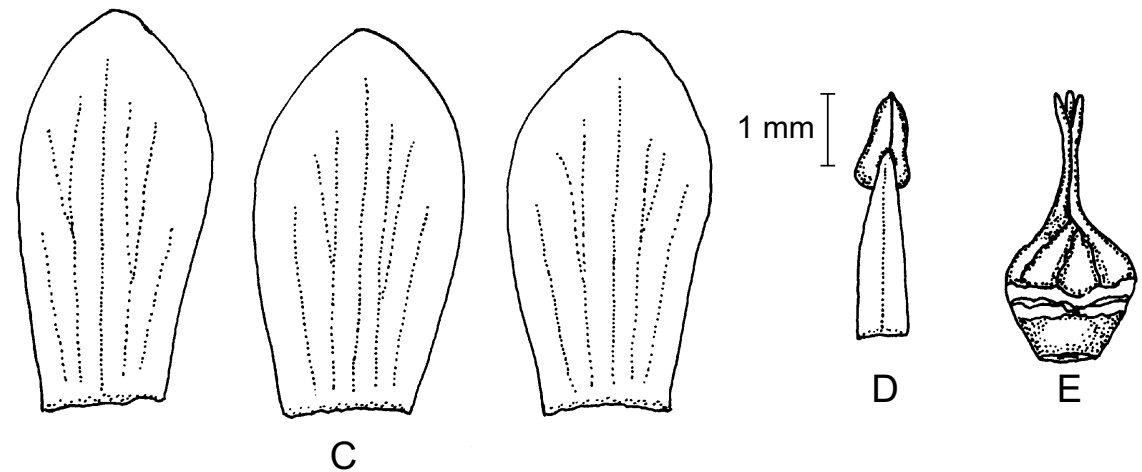

Fig. 2. Hechtia lepidophylla I. Ramírez. Staminate flower. A. floral bract: entire and sectioned at base showing variation on venation; B. sepals: first three apically sectioned and the one at the right not sectioned, showing variation on venation; C. petals; D. stamen; E. pistillode. (Based on I. Ramírez y S. Zamudio 1428, CICY). Illustrations by Anahí López. 


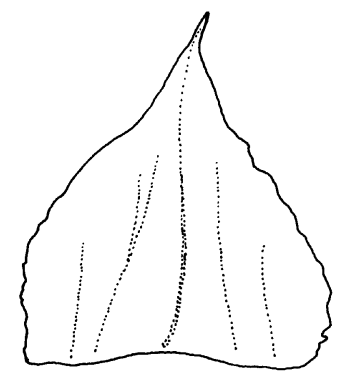

A
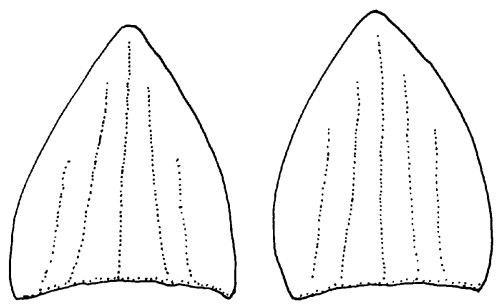

B
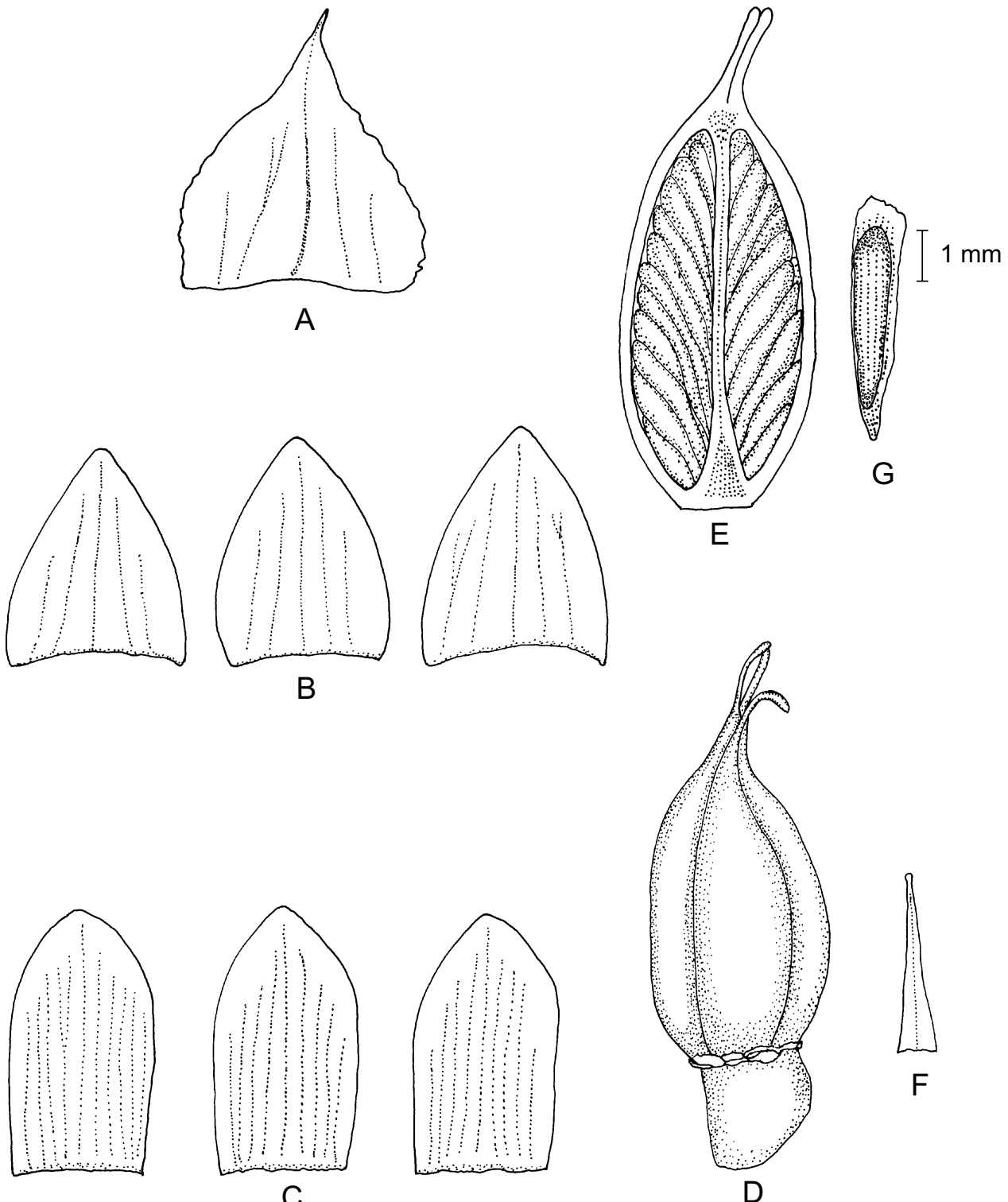

$\mathrm{E}$

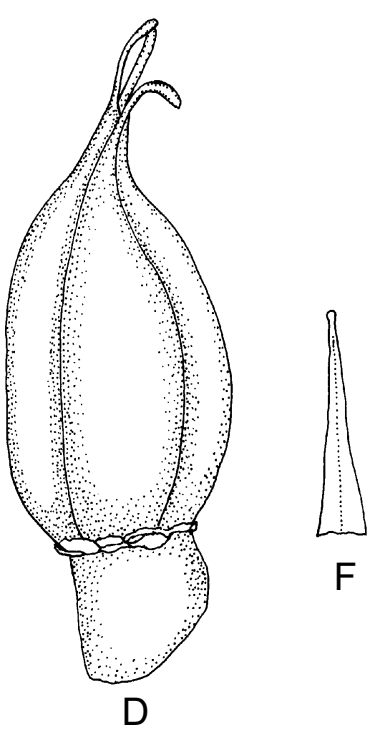

Fig. 3. Hechtia lepidophylla I. Ramírez. Pistillate flower. A. floral bract; B. sepals showing variation on venation patterns; C. petals; D. ovary; E. ovary longitudinally sectioned showing ovule arrangement; F. filament of the staminode; G. ovule. (Based on I. Ramírez y S. Zamudio 1428, CICY). Illustrations by Anahí López. 
3.5-4.1 mm wide, apex shortly acute, margins entire, densely lepidote, especially in abaxial surface, 5-nervate, green, scarious; petals oblong when flattened, concave in natural position, apex rounded, 5.2-5.4 $\mathrm{mm}$ long, 2.8-2.9 $\mathrm{mm}$ wide, mid-longitudinal region thickened, 11-nervate, margins entire, membranaceous, white; ovary superior, oblong-ellipsoidal, 6-7.5 $\mathrm{mm}$ long, $3.5 \mathrm{~mm}$ in diameter, smooth, lepidote; placentation central, ovules white, narrowly cylindrical, 10-11 per locule, filament of staminode narrowly triangular, $3.5 \mathrm{~mm}$ long, $0.8-0.9 \mathrm{~mm}$ wide at base, flat, thin, 1-nervate, white, with a small globular apex; stigma with three slightly curved lobes, ca. $1.5 \mathrm{~mm}$ long, margins sinuate; ovules obovate, with two wings, the more distal longer than the other, $4.5 \mathrm{~mm}$ long, $0.9 \mathrm{~mm}$ wide, wings thin. Fruit a capsule, 7-8 $\mathrm{mm}$ long, 4-5 $\mathrm{mm}$ in diameter, dark brown, shiny and densely lepidote at base; seeds obovate, 4.6-4.8 mm long, 0.9-1 $\mathrm{mm}$ wide, flat, brown, with a small apical, light brown, papyraceous wing.

Type: Mexico, Querétaro, municipio Peñamiller, $5 \mathrm{~km}$ al S de Peña Blanca, matorral micrófilo, "planta de $1 \mathrm{~m}$ de alto, flores escariosas, hojas en roseta basal, abundante”, 2500 m, 1 Julio 1978, S. Zamudio 2923 (Holotype; fruits/ $/$ flowers MO; Isotypes; $\widehat{\jmath}$ flowers XAL; fruits (2 sheets) IEB; $\widehat{\jmath}$ flowers QMEX).

Paratypes: Querétaro, municipio Cadereyta, $6 \mathrm{~km}$ al NE de Higuerillas, matorral micrófilo de Larrea y Fouquieria, "planta perenne, hojas en roseta basal, inflorescencia de $2 \mathrm{~m}$ de alto; flores escariosas", $1600 \mathrm{~m}, 3$ Julio 1987, S. Zamudio y H. Díaz B. 5310 (ð flowers, IEB); Cañada de la Culebra, al N de La Tinaja, matorral submontano sobre laderas calizas, "planta herbácea perenne, hojas espinosas en roseta basal con frutos jóvenes, abundante", $1550 \mathrm{~m}, 8$ Junio 1995, S. Zamudio y E. Pérez C. 9506 (q flowers and fruits, IEB); $5 \mathrm{~km} \mathrm{NE} \mathrm{de} \mathrm{Higuerillas,} \mathrm{2058'19"}$ N, 9994'36" W, 1400 m, matorral micrófilo sobre laderas de rocas lutitas, 14 Julio 2006, I. Ramírez y S. Zamudio 1428 (†, ○’ flowers, CICY); municipio Peñamiller, 6 $\mathrm{km}$ al S de Peña Blanca, matorral desértico micrófilo, "arbusto de $1.5 \mathrm{~m}$ de alto, hojas en roseta basal, abundante", $1450 \mathrm{~m}, 14$ Julio 1979, S. Zamudio 3681 (fruits IEB); municipio Pinal de Amoles, fondo del cañón de Misión.

Hidalgo: municipio San Agustín Metzquititlán, Barranca de Venados, ladera caliza con vegetación de Cephalocereus, 20²8'01" N, 98040'05" W, 1347 m, 8 Agosto 1964, L. González Q. 1189 (fruits, IEB).

Phenology, distribution and habitat: Flowering occurs at the beginning of the rainy season, from June to July. It grows in microphyllous shrublands at 972-2500 
m elevation and is associated with Fouquieria sp., and Agave spp. and species of the family Cactaceae (Fig. 1A). Hechtia lepidophylla is endemic in central Mexico, so far only collected in the states of Hidalgo and Querétaro.

Etymology: The specific epithet refers to the white indumentum that covers the foliar leaves.

The staminate inflorescences of Hechtia lepidophylla could be confused with those of some staminate plants of Hechtia glomerata, a species usually possessing condensed, glomerule-like branches. However, some staminate inflorescences develop long cylindrical branches on 2-divided panicles, resembling those of H. lepidophylla. However, leaf shape and indumentum are very distinctive for each species (see Table 1).

Inflorescence structure (shape and size of branches) as well as floral bract, sepal and petal venation, are variable in populations of Hechtia lepidophylla. Most of the staminate individuals observed in the field have very similar inflorescence length and branch shape, and floral segments, but venation in all floral parts is variable within individuals (Fig. 2). In contrast, pistillate inflorescences are more variable although most of them are 2-pinnate and a few individuals have 1-divided inflorescences but floral bract, sepals and petals are very constant in shape and size with variable venation patterns (Fig. 3).

Specimens of this new entity have been identified in several herbaria as $\mathrm{He}$ chtia argentea Baker, a species that is only known with certainty from the holotype (Kew Hortus s.n., 1870, Mexico (K!; photo GH)) prepared from a staminate plant cultivated at Kew Gardens and presumably collected in Mexico but unknown from wild populations. The study of the type specimen of Hechtia argentea as well as of cultivated plants at Kew Gardens, unambiguously indicate that $H$. argentea is very different from Hechtia lepidophylla. Differences among Hechtia glomerata, H. argentea and H. lepidophylla are depicted in Table 1.

Based only on fragmented portions of the plant, Hechtia lepidophylla is hard to distinguish from other Hechtia species. Diagnostic characters are few, but the leaf indumentum (especially the abaxial surface) and curved blade (even when flattened) are very characteristic of the species in the Flora del Bajío y Regiones Adyacentes area (Fig. 1D). Additionally, leaves of this new entity apparently do not develop red color neither in the lamina nor on the spines and margins. Two sympatric species, Hechtia podantha Mez (Fig. 1C) and H. glomerata have flat, less succulent leaf blade that are glabrous adaxially. Actually, Hechtia glomerata has a very shiny, 


\begin{tabular}{|c|c|c|c|c|c|c|c|c|c|c|c|c|}
\hline 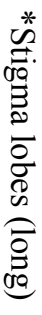 & 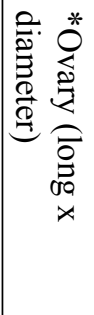 & 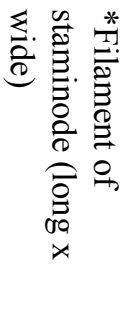 & 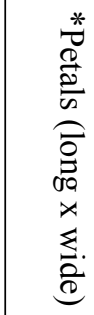 & 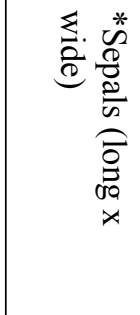 & \begin{tabular}{l}
$*$ \\
\multirow{2}{*}{} \\
0 \\
0 \\
0 \\
0 \\
0 \\
0 \\
0
\end{tabular} & 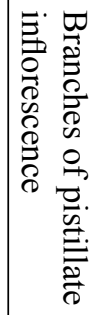 & 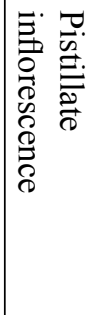 & 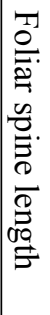 & 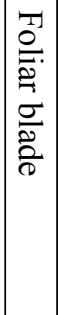 & 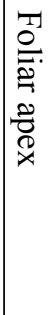 & 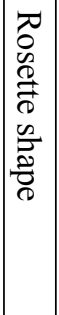 & 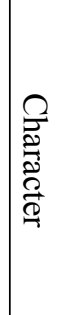 \\
\hline$\omega$ & 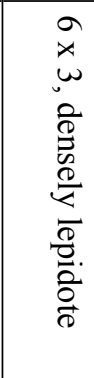 & $\begin{array}{l}N \\
x \\
0 \\
\text { un }\end{array}$ & 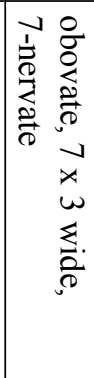 & 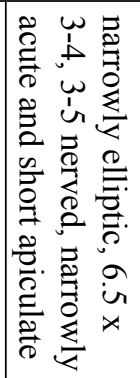 & 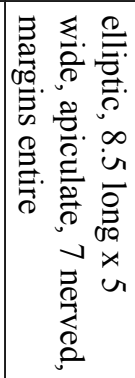 & 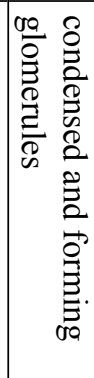 & $\begin{array}{l}1 \\
2 \\
2 \\
2 \\
2 \\
2\end{array}$ & 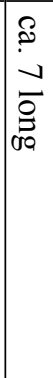 & 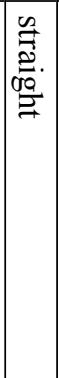 & 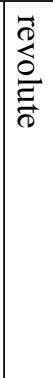 & 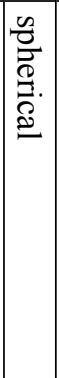 & 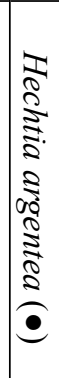 \\
\hline$\frac{8}{\text { Pr }}$ & 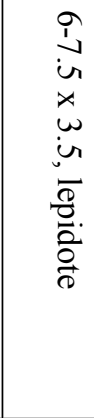 & $\begin{array}{l}w \\
\dot{u} \\
x \\
a \\
\dot{1} \\
v\end{array}$ & 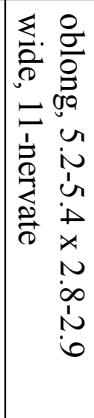 & 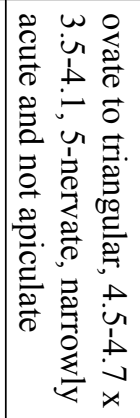 & 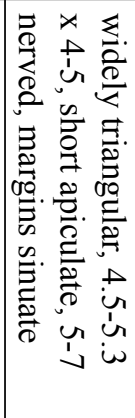 & 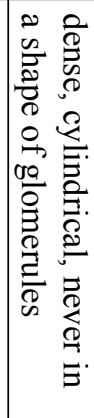 & 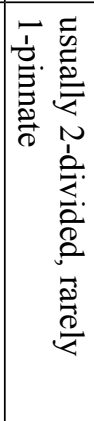 & 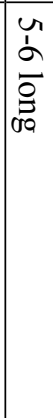 & $\left|\begin{array}{l}\varrho \\
\vdots \\
\vdots \\
\varrho \\
\varrho\end{array}\right|$ & 告 & 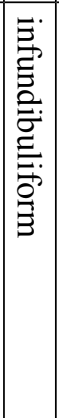 & 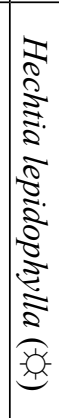 \\
\hline $\begin{array}{l}\stackrel{P}{N} \\
\text { No }\end{array}$ & 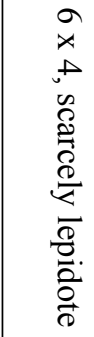 & $\begin{array}{l}N \\
\dot{u} \\
x \\
-\end{array}$ & 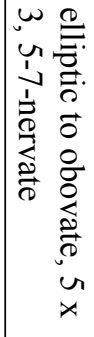 & 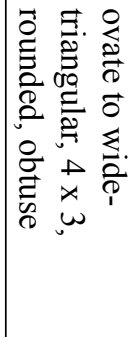 & 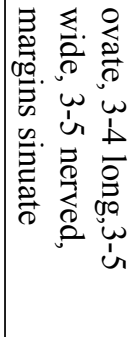 & 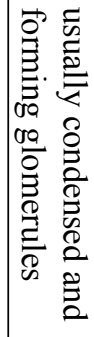 & 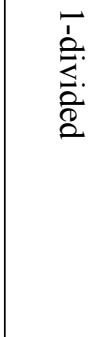 & 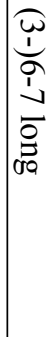 & 告 & 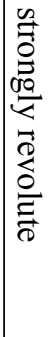 & 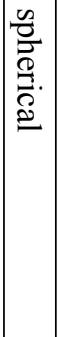 & 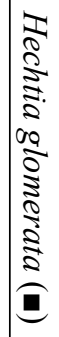 \\
\hline $\begin{array}{l}\stackrel{P}{N} \\
\text { No }\end{array}$ & 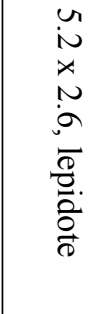 & $\begin{array}{l}\stackrel{N}{N} \\
\dot{x} \\
0 \\
\dot{D}\end{array}$ & 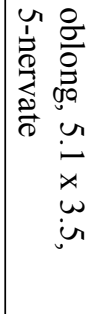 & 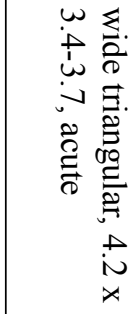 & 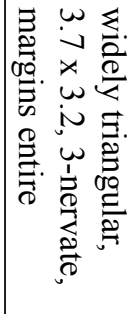 & 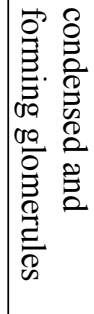 & \begin{tabular}{l}
$N$ \\
1 \\
$ٍ$ \\
\hdashline \\
0
\end{tabular} & 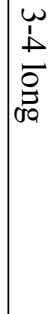 & 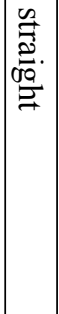 & 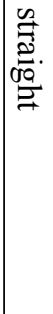 & 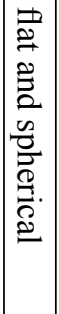 & 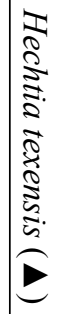 \\
\hline
\end{tabular}

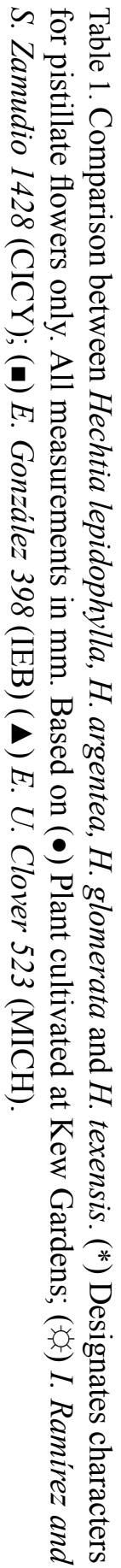


almost lustrous, adaxial foliar surface that sometimes is completely red tinged when blooming, compared with the glaucous leaves of $H$. podantha (occasionally with red margins and spines). A third sympatric species in the mentioned area is Hechtia zamudioi Espejo, López-Ferarri \& I. Ramírez. This species is characterized by flat, wider, much less succulent foliar blades, that have both surfaces completely covered by a white indumentum. Furthermore, this species possesses central inflorescences and flowers of both sexes with green petals.

The new species keys out as Hechtia texensis S. Watson in Smith \& Downs (1974). Burt-Utley and Utley (1987) considered H. scariosa L. B. Sm. as a synonym of $H$. texensis. This species also has lateral inflorescences and fragmentary herbarium specimens could be confused with those of $H$. lepidophylla. They differ in several characters presented in Table 1.

\section{ACKNOWLEDGMENTS}

Thanks to the staff of Flora del Bajío Department and Herbarium IEB for financial support for field work, especially to Sergio Zamudio for field assistance and guidance. Likewise, Luis Hernández Sandoval (Herbarium QMEX) helped collecting additional plants of this new entity. To Germán Carnevali for his help on cultivating several species of Hechtia and for his constant input in the study of this genus. To Roger Orellana and Ian Carnevali for field assistance; to Francisco Chi May and Carlos Jiménez for assistance with herbarium material. To Bruno Manara and Eliana Noguera for their help with the Latin diagnosis. To the Elizabeth Bascom Scholarship sponsors from the Missouri Botanical Garden and the Kew Latin America Research Fellowships Programme (Klarf) for scholarships granted to study their Mexican Bromeliaceae herbarium collections. To the curators of herbaria BM, F, GH, K, MEXU, MICH, MO, P, QMEX, XAL, UAMIZ, UC, and WU for loaning Hechtia specimens. Special thanks to Adolfo Espejo-Serna and Ana LópezFerrari (Herbarium UAMIZ) for their valuable collaboration in the study of Mexican Bromeliaceae. Anahí López drew the illustrations of staminate and pistillate floral parts. Finally, I thank two anonymous reviewers whose comments contributed to improve the quality and clarity of the manuscript.

\section{LITERATURE CITED}

Burt-Utley, K. \& J. Utley. 1987. Contributions toward a revision of Hechtia (Bromeliaceae). Brittonia 39(1): 37-43. 
Espejo-Serna, A., A. R. López-Ferrari, I. Ramírez-Morillo. \& N. Martínez-Correa. 2007. Dos nuevas especies de Hechtia (Bromeliaceae) de México. Acta Bot. Mex. 78: 97109.

Espejo-Serna, A., A. R. López-Ferrari \& I. Ramírez-Morillo. 2008. Dos nuevas especies de Hechtia (Bromeliaceae: Pitcairnioideae) del centro de México. Acta Bot. Mex. 83: $1-13$.

Smith, L. B. \& R. J. Downs. 1974. Pitcairnioideae (Bromeliaceae). Flora Neotropica Monograph 14, Part 1. Hafner Press. New York. 657 pp. 